\title{
Factors Determining the Students' Choice of Private Management College in Kathmandu
}

\author{
Sushil Awale \\ Lecturer \\ Faculty of Management, Central Department of Management, Kirtipur \\ Tribhuvan University, Nepal \\ https://orcid.org/0000-0002-1118-1711 \\ Email: sushil.awale@cdm.tu.edu.np \\ DOI: https://doi.org/10.3126/jom.v4i1.38686
}

\begin{abstract}
Educational service is one of the most lucrative businesses at present. Nepal is getting tremendous growth in education sector. College managers are not clear why student choose particular college. This study analyzes major factors that determine the students' choice of Management College in Kathmandu. This study tries to test the effects of convenient location of the college, friends' choice of college, advertisement, image, past performances, fun, fee, faculties, resource centers and physical environment on choice of college. This study finds image and physical environment of the college only affect significantly in choice of the college.

Keywords: college choice, determinants, service, management college

\section{Introduction}

\section{Background of the Study}

Service sector is growing rapidly throughout the world as human being are getting richer and busier. Educational service is one of the most lucrative businesses in present day. Education is must for every human (Gronroos, 2007; Lovelock et al., 2010; Zeithaml et al., 2011). Education starts from kindergarten to primary level, secondary level, higher secondary level bachelor's level, master's level, $\mathrm{PhD}$ level sequentially. Bachelors and above level education is provided by university constituent campuses and affiliated colleges. Nepalese Universities offers various subjects on management, science, humanities, law, education, medical, engineering, forestry, agriculture (University Grant Commission Nepal, 2017). In Nepal there is growing
\end{abstract}


competition among colleges to attract students. Higher education institutions in Nepal are spending massively in marketing their educational services (Shrestha, 2013, Awale, 2020).

\section{Statement of the Problems and Research Objectives}

College managers are not clear why student choose particular college in Nepal (Awale, 2017; Katuwal, 2011; Shrestha, 2013). Colleges managers do not have clear answers to why different student group chose different colleges, why some colleges are over crowed and some college are almost empty, which dimension of education service is most important for student in selecting college, is there a difference in college choice determinates for male and female etcetera is not clear.

Objects of this study are to identify the factors determining college choice, to analyze the relationship among factors determining college choice and college choice, to examine the effects of major factors on college choice, to compare the choice of college between male and female.

\section{Literature Review}

Reliable service, responsive employees, assured customers, well managed physical environment and company understanding customer feeling is considered good service quality (Zeithaml et al., 2011). In service marketing customers give importance to non monetary costs like time cost, convenience cost, search cost, psychological costs. Simple, convenient, short, customized process of service delivery is equally important. One major indicator of quality education has been the student pass percentage in the board exams (Gronroos, 2007).

According to Price et al. (2003) for many institutions, facilities provided to a high standard, are perceived as having an important influence on students' choice of institution. According to Tang et al., (2004) type of institution, academic reputation ranking, the annual expenditures, geographic region, the existence of professional schools, the size of the faculty and the undergraduate student body, and university presidents' pay and benefits are all significant predictors of college tuition.

Ivy (2010) found five distinct motivational factors were derived from a survey of 427 college students in Leicester city. For all ethnic groups, the student's career is the most important motivating factor; the other motivators are, however, more varied. The influence of the family was most important among Pakistani and African students. Indian and "other" Asian students were most strongly associated with academic and 
social motivators. White applicants, on the other hand, had no relative strengths with regard to common motivators. What was perhaps more apparent was how unimportant family was on influencing choice. There were also differences between the ethnic groups and the university type applied for.

Somers et al. (2006) identified eight determinants of college choice. They are cost, financial variable, social environment, aspirations, institutional characteristics, institutional climate, students background and educational achievement of the college. According to Lee and Chatfield (2015) many studies on college student decisionmaking use economic and sociologic theoretical frameworks to examine factors of college choice. First, the economic models focus on the econometric assumptions that prospective college students think rationally and make careful cost-benefit analyses when choosing a college (Hossler \& Gallagher, 1989). Second, the status-attainment models assume a utilitarian decision-making process that students go through in choosing a college, specifying a variety of social and individual factors leading to occupational and educational aspirations (Shrestha, 2013). Third, the combined models incorporate the rational assumptions in the economic models and components of the status attainment models. Most combined models divide the student decision-making process into three phases: aspirations development and alternative evaluation; options consideration; and evaluation of the remaining options and final decision (Jackson, 1982). Shrestha (2013) identified public is concerned primarily with credibility and trust of the program. They consider education has quality when they assume the education programs develop graduate employability and practical skills among the students. Therefore, they are concerned with process and output of any education programs. Another important finding is that public is concerned with the process of delivering education with practical curriculum and practical delivery of the faculty. They were not at all interested in input such as infrastructure. When they measure quality as attributes alone, they consider curriculum and faculty important factors but when they compare the attributes with the price, they would give attention to employability and faculty. Although competent faculty has less contribution in enhancing perceived quality and perceived value, though they are important contributing factors to make curriculum practical and deliver practical skills to enhance students' employability. They finally increase reputation as symbolic attributes of education program. 
Decision-making in higher education considers three different levels of students' choice: global, national, and curriculum level (Lee \& Chatfield, 2015). At global level focuses on why students choose to study abroad. Student migration and study abroad has become a huge business matched by tremendous investment, especially among western countries. Study has identified a range of factors influencing course like preference course among employers; graduate satisfaction from the course; graduate employment from the course; the quality of teaching in the course.

Zimmerman et al. (2000) has identified "push and pull" factors which operate along the students' decision. Dreher and Poutvaara (2005) have suggested that economic and cultural forces play a role in shaping the international students' migration markets choice of higher education institution. Foskett et al. (2006) found that students consider more carefully economic factors in times of distress and financial difficulty. These factors include job opportunities to supplement their incomes, accommodation costs and family home proximity.

Lipman (2011) found solid performer students are more likely to enroll at a public institution in an economic downturn. He claimed parents are deeply involved and influential to their high-achieving children's college choices. The report also found open houses, dialogue with college friends, alumni, and admitted-student programs are extremely influential to students. Streitfeld (2009) mentioned media can play an important role in attracting foreign students as they have limited access to school information.

Every year college grower is increasing for higher education. Due to development of the education market many companies have ventured into this business. There has been huge competition among the colleges proving educational service. It has become challenging to collect the students for one's college. Owners of the colleges are curious on what are the determinants of student choice of college. College provides educational services. Services are selected based on its location, image, timeliness, access to its information rather than mere monetary price (Zeithaml et al., 2011). Students say they are attracted to the colleges that are highly advertised, offers extracurricular activities/fun, has good past academic records, are affiliated to credible university. Academicians says students look for past results, infrastructure, fee, affiliation, years of experience (Awale, 2011; Gronroos 2007, Koirala, 2005; Uprety \& Chhetri, 2014; Zeithaml, 1988). Study on identifying factors that determine the choice of the management college in Kathmandu is illusive. 
This study analyses the effect of independent variables convenience location, friends' choice, advertisement, fun, fee charged, resources and physical environment on dependent variable choice of the college.

Figure 1

Conceptual Framework: Factors Determining Choice of College

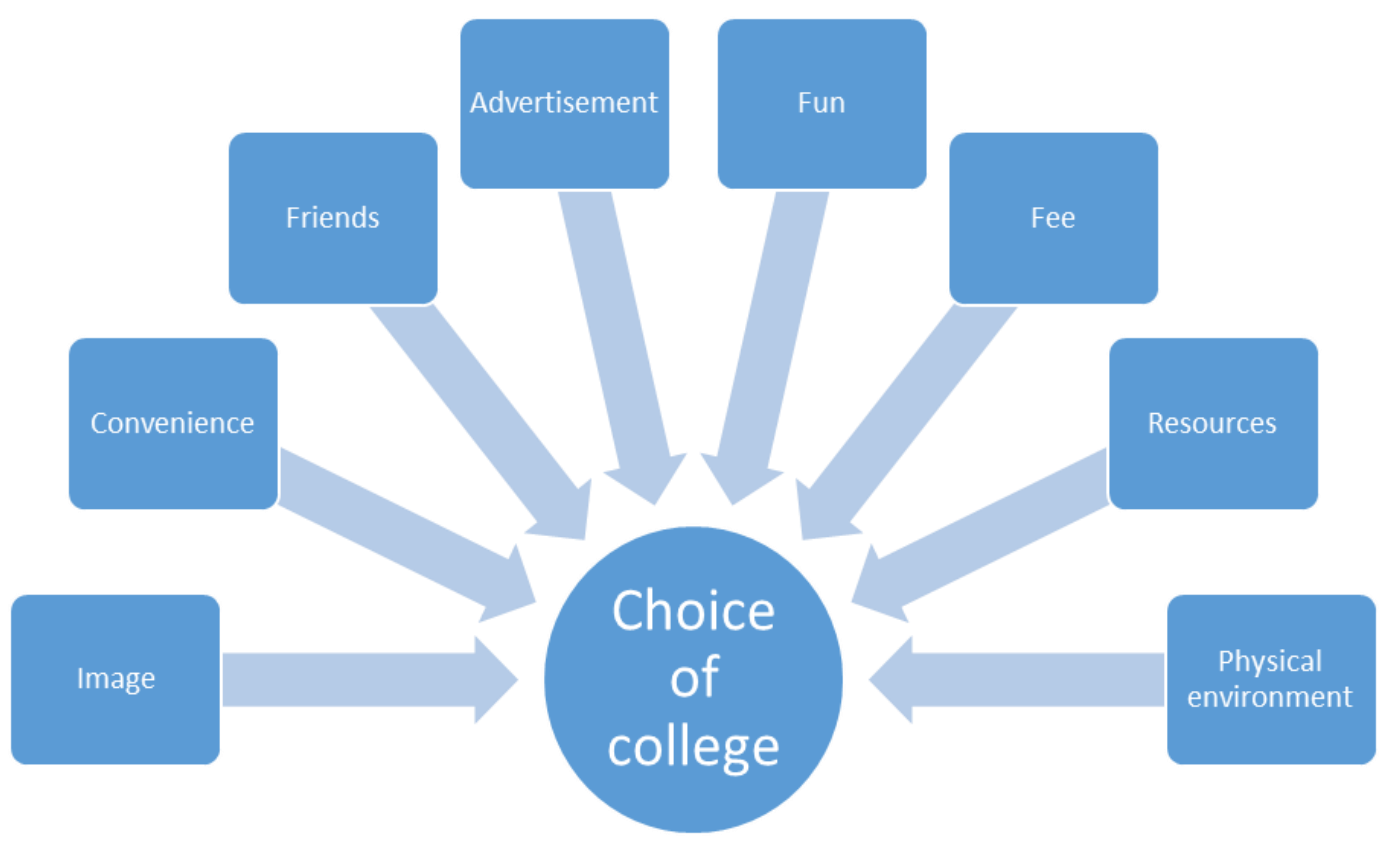

\section{Research Methods and Materials}

This is the descriptive research design. It will be based on quantitative data analysis. It will be based on students' survey. This study is based on primary data analysis. Data is collected through questionnaires. Information on demographic of the respondent, college chosen, effecting factors in determining college choice, behavioral factors were collected. Reliability of scale was measured by Cronbach alpha. Face validity, convergent validity, discriminant validity was tested.

Population of the study is all undergraduate management students of Kathmandu. Based on Krejcie and Morgan (1970) table sample size for this study was 384. Five hundred questionnaires were distributed, 416 completely filled questionnaires were analyzed. Three colleges were selected based on judgmental sampling. Three well known colleges in Kathmandu were selected. Among three colleges two were 
affiliated to Tribhuvan university (Peoples' Campus, DAV College of Management) and one was affiliated to Pokhara University (Uniglobe College). Equal number of questionnaires were distributed in three colleges. Convenience sampling method were applied while selecting the students.

Instrument is developed based on conceptual framework. Scales are borrowed from previous studies that are valid and reliable. Minimum two items were used to collect the information on each variable. Instruments have been borrowed from the study of Shrestha (2013) and Marketing Scales Handbook of Bruner (2009). After testing the instrument on few of the respondent whether they understand what is asked and whether it is convenient to answer, then formal data collection was preceded. Appointment was taken with the college authority to meet the student in convenient time. Purpose of the study and survey instrument was briefed to the respondent before respondents self-administered the instrument. Students were guided and supervised while administering the instrument in the class.

\section{Table 1}

Reliability Test on Summated Variables

\begin{tabular}{lcc}
\hline \multicolumn{1}{c}{ Variables } & Cornbach Alpha & No of items \\
\hline Choice & 0.773 & 2 \\
Image & 0.774 & 3 \\
Convenience & 0.887 & 2 \\
Friends Choice & 0.710 & 2 \\
Advertisement & 0.848 & 2 \\
Fun & 0.833 & 2 \\
Fee Charged & 0.545 & 2 \\
Resource & 0.536 & 2 \\
Physical Environment & 0.452 & 2 \\
\hline
\end{tabular}

After collection of data glances given on the collected instrument whether it is filled seriously and completely. After preliminary scanning the collected questionnaires acceptable questionnaires each are given sequential number. Questionnaire are properly coded and entered into the SPSS file in computer. Sample profile, factor analysis, reliability test, validity test, ANOVA, correlation, regression analysis were done. Regression equation is formed based on principle of least square method. Regression 
analysis was done to find out the significance of independent variables and how much each independent variable contributes to the determination of college choice. Tables, charts, diagrams were used to present the data.

\section{Results and Discussion}

After collection, processing and analysis of data following results are revealed. Later results are discussed with prevailing theories and empirical findings in this section. Out of 416 respondent students, male respondent students were 160 and female respondent student were 256. In this study differences in responses based on gender type revealed following results on various factors determining college choice.

\section{Result Difference due to Gender}

\section{Table 2}

ANOVA Test on Demographic Variables

\begin{tabular}{llccrrr}
\hline \multirow{2}{*}{ Variables } & Sex & N & Mean & Std. Deviation & F & Sig. \\
\hline \multirow{2}{*}{ Image } & Male & 160 & 3.7094 & .96482 & & \\
& Female & 256 & 4.1094 & .65883 & 6.243 & .014 \\
& Total & 416 & 3.9579 & .80802 & & \\
Convenience & Male & 160 & 3.6000 & 1.38305 & & \\
& Female & 256 & 3.1953 & 1.40751 & 2.062 & .154 \\
& Total & 416 & 3.3510 & 1.40540 & & \\
Friends choice & Male & 160 & 3.5000 & 1.34212 & & \\
& Female & 256 & 3.3008 & 1.13230 & .660 & .419 \\
& Total & 416 & 3.3774 & 1.21479 & & \\
Advertisement & Male & 160 & 2.6250 & .99195 & & \\
& Female & 256 & 2.7266 & 1.22452 & .195 & .660 \\
& Total & 416 & 2.6875 & 1.13674 & & \\
Fun & Male & 160 & 3.0000 & 1.25064 & & \\
& Female & 256 & 2.9219 & .90509 & .136 & .713 \\
& Total & 416 & 2.9519 & 1.04630 & &
\end{tabular}




\begin{tabular}{llllllll} 
& Male & 160 & 2.9875 & 1.18477 & & \\
Fee charged & Female & 256 & 3.2578 & 1.09288 & 1.411 & .238 \\
& Total & 416 & 3.1538 & 1.13115 & & \\
& Male & 160 & 4.4250 & .78078 & & \\
Resource & Female & 256 & 4.5469 & .67093 & .715 & .400 \\
& Total & 416 & 4.5000 & .71394 & & \\
Physical environment & Male & 160 & 3.2375 & 1.04383 & & \\
& Female & 256 & 3.5781 & .90947 & 3.079 & .082 \\
& Total & 416 & 3.4471 & .97273 & & \\
Choice & Male & 160 & 3.7500 & .93370 & & \\
& Female & 256 & 3.8438 & .86774 & .271 & .604 \\
& Total & 416 & 3.8077 & .89037 & & \\
\hline
\end{tabular}

ANOVA table above shows that there is significant difference between male and female only on one factor. It is found that there is significant difference regarding importance given by male and female to image of the college while selecting the management college in Kathmandu. Study finds male and female both give similar importance to remaining factors in selecting college.

Table 3

Correlation Among Variables

Correlations

\begin{tabular}{ccccccccccc}
\hline $\begin{array}{c}\text { Serial } \\
\text { no. }\end{array}$ & Variables & 1 & 2 & 3 & 4 & 5 & 6 & 7 & 8 & 9 \\
\hline 1 & Image & 1 & & & & & & & & \\
2 & Convenience & .03 & 1 & & & & & & & \\
3 & Friends choice & $.37^{* *}$ & -.04 & 1 & & & & & & \\
4 & Advertisement & $.26^{* *}$ & $.12^{*}$ & $.33^{* *}$ & 1 & & & & & \\
5 & Fun & $.21^{* *}$ & $.19^{* *}$ & .08 & $.18^{* *}$ & 1 & & & & \\
6 & Fee charged & $.43^{* *}$ & $.25^{* *}$ & -.01 & .01 & $.11^{*}$ & 1 & & &
\end{tabular}




\begin{tabular}{lccccccccccc}
7 & Resources & $.46^{* *}$ & .08 & $.19^{* *}$ & .04 & $.26^{* *}$ & $.25^{* *}$ & 1 & & \\
8 & Physical & & .07 & $-.12^{* *}$ & .04 & $.14^{* *}$ & $.18^{* *}$ & -.05 & $.14^{* *}$ & 1 & \\
9 & environment & .07 & & & & & & & & \\
9 & Choice & $.57^{* *}$ & $.11^{*}$ & $.16^{* *}$ & $.25^{* *}$ & $.13^{* *}$ & $.31^{* *}$ & $.16^{* *}$ & $.24^{* *}$ & 1 \\
\hline
\end{tabular}

Note. ${ }^{* *}$. Correlation is significant at the 0.01 level (2-tailed).

*. Correlation is significant at the 0.05 level (2-tailed).

Table 3 shows significant correlation between dependent variable and independent variables of the study.

\section{Table 4}

Regression Analysis

Coefficients

Independent variables $\quad$ Standardized Coefficients $\quad$ t $\quad$ Sig. R square $\quad$ F $\quad$ Sig Beta

(Constant)

$\begin{array}{llll}2.137 & 035 & 0.417 \quad 8.420 & 0.000\end{array}$

Image

.585

5.490 .000

Convenience

$-.024$

$-.281 \quad .779$

Friends choice

$-.058$

$-.646 .520$

Advertisement

.107

1.222 .225

Fun

.000

$.001 \quad 999$

Fee charged

.106

1.139 .257

Resource

$-.170$

$-1.827 .071$

Physical environment

Note. a. Dependent Variable: choice

Above table shows Regression model is fit as $\mathrm{p}$ values is significant, that is less than 0.05 . $\mathrm{R}$ square is 0.42 , that is independent variables explains $42 \%$ change in 
dependent variable (choice of the college). The table above shows that most important determinant in college choice is image of the college; second most important determinant is physical environment of the college. Remaining factors are insignificant. Advertisement, fee, convenience location, friends' choice, fun factors have been found insignificant to students while choosing college of management for students in Kathmandu.

\section{Findings}

Nine constructs were formed. Independent variables are convenience, friends' choice, advertisement, fun, fee charged, resource and physical environment. Dependent variable is choice of the college. Study finds most important determinant in college choice is image of the college; second most important determinant is physical environment of the college. Remaining factors are insignificant. Advertisement, fee, convenience location, friends' choice, fun factors have been found irrelevant to students while choosing college of management for student of Kathmandu.

ANOVA table showed that there is significant difference between male and female only on one factor. It is found that there is significant difference regarding importance given by male and female to image of the college while selecting the management college in Kathmandu. Mean score on image for male is 3.709 and mean score for female is 4.109 .

Male and female both give similar importance to remaining factors in selecting college.

Out of nine construct 6 has higher than 0.7 Cronbach alpha which is considered good reliability and three construct have Cronbach alpha between 0.452 to 0.545 . There was significant correlation between dependent variable and independent variables. Regression model is fit as $\mathrm{p}$ values is significant that is less than 0.05 . $\mathrm{R}$ square is 0.42 , that is independent variable explains $42 \%$ change in dependent variable choice of the college.

\section{Discussion}

Though previous studies show fun, friends and family have influence on student's choice of college but this study do not find these variable significant. Students are not giving the importance to fun factor offered by college because the students think that fun is obvious in the college since college is gathering of like-minded age groups (Zeithaml et al., 2011; Awale, 2011). Family influence is also eroding because 
students are getting very independent due to technology, awareness, access to every information (Shrestha, 2013). Friends influence is also eroding because easy access to new friends through social network. Today people do not have to worry about losing friends because they have very easy access to new friends through technology like facebook, cell-phone, frequent trade fair and fete taking place (Lee \& Chatfield, 2015).

Service marketing principles have emphasized the important of convenience location; competent faculties but this study does not find it significant here in Nepal. College in Kathmandu are spending huge budget in advertising their college but this study reveal that advertisement do not convince the student to join the college. Service marketing principles prescribe word of mouth, testimonial, endorsement are more effective than advertising (Zeithaml et al., 2011). Companies and advertisement agencies not having right knowledge about developing the effective advertisement (Awale, 2011). Competent faculty are also not attracting student may be because students are getting awareness about major contribution of self-learning in their performance, learning by doing own self; role of the student is more important in the students' performance. Service is co-created together with customers (Zeithaml et al., 2011).

Though convenience cost is also one of the important non monetary cost customers considers in choosing the service vendor (Gronroos, 2007) but assurance is found to be more powerful dimension in choosing college. Students like to be assured about they completing their education in predefined period, timely results, academic calendar to be followed, their degree is valid and appreciated, their college is rectified by the government (University Grant Commission Nepal, 2017).

Monetary cost has lesser importance in choosing the service (Gronroos, 2007). This study also has revealed that fee of the college is insignificant factor is deciding the college.

Most of the educational institutes have been portraying their huge attractive buildings in their advertisements to attract the students (Awale, 2017). This study has found that the physical environment (building, exterior and interior decorations) of the college impress the student.

Most of the colleges have portrayed their students as lion, sharp pencil, golden egg, boss etc. Many colleges in Nepal have named them self like King's College, Einstein college, Ace Institute, Apex College, Prime college, Premier college, Presidential 
college etc. to reflex their image (University Grant Commission Nepal, 2017). This study has found image if the college matter very much which is consistent with branding theories (Kotler et al., 2013).

\section{Implication}

To attract the students, college should focus on building image of the college. Public relations of the college must be enhanced. College should have good building, interior decorations, well equipped classrooms and good atmosphere to attract the students.

Separate studies for undergraduate as well as post graduate students' choice of college can be pursued in future. Colleges offering different subjects like management studies, science studies, and humanities etcetera can be studied separately or comparatively. Advanced factor analysis tools can be used for refinement of the factors and minimizing the factors. Future research can check whether advertisement can boost the image of the college or not since one of the objectives of advertisement is to build the image of the company too. Private colleges, public colleges and government colleges can be studied separately in future too. Factor determining choice of college might be different for different university therefore university wise study give specific information.

\section{Conclusions}

The most important factor that determines the choice of the management college in Kathmandu is the image of the college. Next important factor in selecting college is physical environment of the college. Influence of family and friends on college is eroding. Service marketing itself being the new subject there is huge scope of further research on educational service and factors determining choice of educational institution. Most of the advertising money is been wasted in Nepal. Effective Advertising must be created.

\section{References}

Awale, S. (2011). Love Triangle in Marketing. GCM Management Journal, 1, 11-19.

Awale, S. (2020). Market Orientation of Tribhuvan University Colleges. Journal of Nepalese Business Studies, 13(1), 135-146.

Awale, S. (2017). Services Marketing with Nepalese Perspective (4e). Buddha publication. 
Dreher, A., \& Poutvaara, P. (2005). Student flows and migration: an empirical analysis, CESIFO Working Paper, No. 1490 Category 4 Labour markets.

Foskett, N., Maringe, F. \& Roberts, D. (2006). Changing Fee Regimes and their Impact on Student Attitudes to Higher Education. Higher Education Academy, UK.

Gronroos, C. (2007) Service Management and Marketing. Wiley India Pvt. Ltd.

Hossler, D., \& Gallagher, K. (1989). Studying college choice: A three-phase model and the implication for policy makers. College and University, 2, 207-21.

Ivy, J. (2010) Choosing futures: influence of ethnic origin in university choice. International Journal of Educational Management, 24 (5), 391 - 403

Jackson, G. (1982). Public efficiency and private choice in higher education. Educational Evaluation and Policy Analysis, 4, 237-47.

Krejcie, R. V., \& Morgan, D. W. (1970). Determining sample size for research activities. Educational and Psychological Measurement, 30, 607-610.

Katuwal, S. B (2011). Global Financial crisis and higher education in Nepal. International Journal of Business Management, Economics and Information Technology, 3 (1), 39-45.

Koirala, P. (2005). Vision and Mission of Management Education in Nepal. Tribhuvan University Journal, XXV (1), 27-32.

Kotler, P., Keller K. L., Koshy A., \& Jha, M. (2013) Marketing Management. Pearson Education.

Lee, S. J. \& Chatfield, H. K. (2015). A Multivariate Repeated Measure Analysis of Importance and Performance on College Choice: A Case Study of UNLV Hotel College Students, Journal of Teaching in Travel \& Tourism, 15 (2), 125-149

Lipman, M. (2011). Philosophy for Children: Some Assumptions and Implications. ETHICS IN PROGRESS. 2. 3-16.

Lovelock, C., Wirtz J., \& Chatterjee J. (2010). Services Marketing. Pearson Education Asia.

Price, I., Matzdorf, F., Suckley, L. \& Agahi, H. (2003). The impact of facilities on student choice of university. International Journal of Educational Management. 21. 212-222. 
Shrestha, B. K. (2013). Public perception of the quality of academic education program. Journal of Education and Research, 3(1), 52-64.

Somers, P., Haines, K., \& Keene, B. (2006). Toward A Theory of Choice for Community College Students. College Journal of Research and Practice, 20, 5367.

Streitfeld, R. (2009, April 17). Unemployed workers heading back to school. CNN. https://www.cnn.com/2009/LIVING/02/14/unemployment.education/index.html

Tang T.L., Tang D.S. \& Tang C.S. (2004). College tuition and perceptions of private university quality. International Journal of Educational Management, 18, 304-316.

University Grant Commission Nepal (2017). Education Management Information System. Retrieved 2017 November 23 from http://www.ugcnepal.edu.np

Uprety, R. \& Chhetri, S. B. (2014). College Culture and Student Satisfaction. Journal of Education and Research, 4 (1), 77-92.

Zeithaml, V. A. (1988). Consumer perceptions of price, quality, and value: A meansend model and synthesis of evidence. Journal of Marketing, 52, 2-22.

Zeithaml, V. A., Bitner, M. J., Gremler, D. D., \& Pandit, A. (2011). Services Marketing. Tata McGraw-Hill.

Zimmerman, K., Bauer, T., \& Loftstrom, M. (2000). Immigration policy: assimilation of immigrants, evidence from 12 OECD countries. Swedish Economic Policy Review, 7(2), 11-53. 